\title{
Analysis of Business Performance according to the Characteristics of Certified Business Operators in the Rural Convergence Industry in Chungnam
}

\section{충남 농촌융복합산업 인증사업자 특성에 따른 사업성과 분석}

Sang Ho Park ${ }^{1}$, Keoung Shim Kang ${ }^{2}$, Jun Sang Yoon ${ }^{3}$

박상호 ${ }^{1}$, 강경심 2 , 윤준상 3

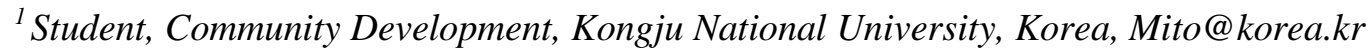

${ }^{2}$ Professor, Food Service Management and Nutrition, Kongju National University, Korea, kkshim@kongju.ac.kr

${ }^{3}$ Professor, Community Development, Kongju National University, Korea, jsyoon@kongju.ac.kr

Corresponding author: Keoung Shim Kang

\begin{abstract}
The purpose of this study is to analyze the business performance and propose a development plan for certified business operators for the rural convergence industry in Chungnam. The results of examining the main general characteristics of 135 certified business operators from 2015 to 2019 are as follows. The ratio of certified business operators with 5 to 10 years of experience, $50 \mathrm{~s}$, and complex type is high. Also, the proportion of operators with increasing sales and employees is high. It was analyzed that sex, region, convergence type, business type, subsidiary project support, and age group did not significantly affect sales and employees growth. Furthermore, the operating period did not significantly affect the employee growth rate, but it was analyzed to have a significant effect on the sales growth rate $(\mathrm{p}<0.05)$. In Duncan Test (LSD) of the sales growth rate, the average difference between 5 years or less, and 5 years to 10 years, more than 10 years was analyzed to have a significant difference in $p<0.05$. And the longer the operating period, the higher the sales growth rate. The business operation period is considered an important performance indicator as it shows the business operation capacity of the management company. Therefore, it is necessary to continuously promote the capacity building education of certified business operators and support customized expert consulting. In addition, it is necessary to create conditions for key talents to continue working and to establish a customized policy support system for each stage of growth.
\end{abstract}

Keywords: Rural Convergence Industry, Certified Business Operators, Business Performance, Business Operation Period, Sales Growth Rate, Employees Growth Rate

요약: 본 연구의 목적은 충남 농촌융복합산업 인증사업자의 사업성과 분석과 발전방안 제안이다. 연구결과 충남 인증사업자 135개소의 2015년 2019년 기준 일반적 특성은 5년 10년 경력 법인사업자와 50 대, 융복합유형 비율이 높고, 매출액과 일자리는 증가하고 있는 경영체의 비중이 높은 것으로 조사되었다. 성별, 지역, 융복합유형, 사업형태, 보조사업 지원 유무, 연령대는 모두 매출액과 일자리 증가율에 유의한 영향을 미치지 않는 것으로

Received: September 19, 2021; $1^{\text {st }}$ Review Result: November 6, 2021; $2^{\text {nd }}$ Review Result: December 24, 2021 Accepted: January 29, 2022 
분석되었고, 운영 기간은 일자리 증가율에 유의한 영향을 미치지 않았으나 매출액 증가율에는 유의한 영향을 미치는 것으로 분석되었다 $(\mathrm{p}<0.05)$. 매출액 증가율 사후검정(LSD) 결과 5 년 이하와 5 년 10 년, 10 년 초과 간의 평균 차이는 통계적으로 유의미한 결과를 보였고 $(\mathrm{p}<0.05)$, 운영 기간이 길수록 매출액 증가율은 높은 경향을 보였다. 연구결과 운영 기간은 사업운영 역량을 보여주는 것으로 중요한 성과 지표로 판단할 수 있으며, 이를 위해 인증사업자의 역량 강화교육의 지속 추진과 맞춤형 전문가 컨설팅 지원, 핵심 인재가 지속 근무할 수 있는 여건 조성, 성장 단계별 맞춤형 정책 지원 체계 구축이 필요하다.

핵심어: 농촌 융복합 산업, 인증 사업자, 사업 성과, 매출액 증가율, 일자리 증가율

\section{1. 서론}

우리나라 농업·농촌의 실정은 농가 및 인구의 지속 감소, 농업인 고령화, 소규모 영세 농가 증가, WTO 및 FTA 시장개방으로 인한 농산물 가격하락 등 대내.외적 여건 변화로 인해 농업소득 감소와 지역사회 활력 침체를 겪고 있었으나, 베이비붐 세대(1955년 1963년생)의 은퇴, 정부의 청년지원 정책 확대 등으로 귀농.귀촌 인구 증가와 청년인구 유입이 가속화되었고, 농업·농촌에 새로운 활력 증대와 농업·농촌의 유무형 향토자원에 대한 다원적 가치가 새롭게 조명받고 있다.

농업·농촌은 문화·휴양적 가치가 증대되면서 힐링(Healing)의 장소로 확산되었고, 바쁜 일상 속에서 삶의 가치와 여가를 중시하는 문화 형성과 주 5 일 근무 정착과 대체 공휴일 제도 시행 등으로 인한 생활패턴 변화는 농촌의 변화를 가속화하고 있다[1]. 이러한 농업·농촌의 새로운 가능성을 바탕으로 정부는 '2013 2017 농업.농촌 및 식품산업 발전계획'에서 농촌의 유무형 자원인 1차산업과 2차산업(제조·가공), 3차산업(체험·관광 .서비스)의 융복합을 통한 새로운 부가가치와 지역 일자리 창출로 인한 지역경제 활성화에 주안점을 두었고 농촌융복합산업 제도를 도입하여 주요정책으로 추진하고 있다[2].

정부는 ‘제4차 농어촌 삶의 질 기본계획(2020 2024)'을 통한 농업·농촌의 위기상황 극복과 농촌 가치 증대를 목표로 5년간 49조원의 지원을 추진하고 있으며[3], ‘누구나 살고 싶은 복지 농어촌 조성’이라는 슬로건을 중심으로 한 삶의 질 향상을 위한 복지 서비스 강화, 경제 활동 다각화 및 경제 활성화, 교육기회 보장, 농어촌 문화자원 고도화 및 정주기반 구축 등과 농촌융복합산업 육성 추진이 포함되어 있다[4].

2014년 6월 농업 고부가가치화 기반 마련과 농업·농촌 발전, 농촌경제 활성화 도모를 통한 농업인과 농촌주민의 소득증대 및 국민경제 발전에 이바지함을 목적으로 「농촌융 복합산업 육성 및 지원에 관한 법률(이하 농촌융복합산업법)」을 제정하였고, 2015년 6월 시행되었다[5]. 동법 제8조 제14조에 따라 농촌융복합산업 핵심 경영체 육성을 위해 사업자 인증제도를 도입하였으며, 인증사업자 육성 결과 전국 인증사업자는 2015년 802 개소에서 2019년 1,624개소로 2배 이상 증가하였다[2].

또한, 농촌융복합산업 기반조성을 위해 동법 제 15 조 제 29 조의 2 를 통해 인증사업자 실태조사 및 통계 작성·관리, 농촌융복합산업 종합정보관리시스템 구축·운영, 농촌융복합 산업 지원 전문기관 지정, 농촌융복합산업 연구·개발, 전문인력 양성, 창업 지원, 관련 산업과의 협력 장려, 판로 지원, 인증자협회 설립, 금융지원, 홍보 및 교육, 가공시설 내 
판매장 운영 등의 다양한 정책을 육성.지원하고 있다[2].

한편, 충남도는 2011년 전국 최초로 충남연구원 내에 농촌융복합산업지원센터를 설치하고, 농업·농촌의 부가가치 창출과 농촌융복합산업 육성을 위해 다양한 정책을 지원함으로써 인증사업자의 단기간 양적 팽창과 농촌융복합산업에 대한 충남도 내 인지도 향상 성과를 보였다. 하지만 2019년 말 기준 신규 인증 후 재인증 포기 및 재인증 탈락 비중이 $25.8 \%$ 로 조사되었고, 농업경영체 중 농촌융복합산업 인증사업자 비율은 $10.4 \%$ 에 그치고 있다[6]. 이런 문제를 극복하고 충남 농촌 지역경제 활성화 및 농가소득 제고를 위해서는 농촌융복합산업 인증경영체의 특성에 따른 사업성과 파악과 정책 대안 모색이 필요하다고 할 수 있다.

농촌융복합산업 관련 연구는 농촌융복합산업 활성화 및 발전 방안 연구가 대부분이며 [7-11], 교육실태 분석[12], 융복합 유형 및 성장단계별 성공요인 분석[13][14], 경영 성과 및 재무성과 분석[15-19] 등의 연구가 지속되고 있는 것을 확인할 수 있으나, 2015 년부터 제도화된 농촌융복합산업 인증사업자의 사업 특성 관련 성과를 밀도 있게 분석한 연구는 미흡한 편이다. 농촌융복합산업 인증사업자 대상 연구는 인증 업체 전문 인력 실태조사[20], 농촌융복합산업 인증경영체의 성장단계별 특징 파악을 위한 매출액 결정 요인 분석[21], 2016년 인증경영체 실태조사 군집분석을 통한 유형별 특성 분석[22], 농촌융복합산업 인증기업 중심 기업가정신, 전략지향성과 경제적.사회적 가치 관계 연구 [23], 농촌융복합산업 인증기업체 매출과 정부 지원사업 연관성 분석[24], 전남 인증경 영체 대상 현장 조사[25], 충북 농촌융복합산업 인증경영체 현황 및 육성 방안 연구[1], 인천 6차산업화 발전방안 연구[26] 등으로 농촌융복합산업 인증사업자를 대상으로 한 연구 중 사업성과를 구체적으로 제시한 사례는 미흡한 경향을 보이고 있다.

본 연구의 목적은 2015년부터 2019년까지 정부가 정책적으로 양성한 농촌융복합산업 인증사업자의 운영 특성에 따른 사업성과 분석을 통해 추진 성과를 도출하고 향후 운영 방안을 제안하는데 있다. 이러한 목적 달성을 위해 본 연구에서는 농촌융복합산업 사업자 인증제도의 지원정책 및 현황을 파악하고 충남 소재 135 개 농촌융복합산업 인증 사업자의 제반 여건을 분석한 후 인증사업자의 일반적 특성과 사업성과의 연관성을 분석한 후 이를 토대로 향후 운영 방안을 제안하고자 한다.

\section{2. 이론적 배경}

\section{1 농촌융복합산업 사업자 인증제도}

농촌융복합산업 사업자 인증제도는 2020년 농림축산식품부에서 제시한 「농촌융복합 산업 활성화 지원 세부사업 추진 요령[27]」과 「농촌융복합산업 육성 및 지원에 관한 법률[5]」을 기준으로 작성되었다.

\subsection{1 농촌융복합산업 사업자 인증}

농촌융복합산업 사업자 인증을 취득하기 위해서는「농촌융복합산업법」 제 2 항에 의거 농림축산식품부령으로 정하는 바에 따라 사업계획서를 작성하여 농림축산식품부 장관에게 제출하여야 한다. 사업계획서에는 추진사업 명칭, 사업자명 및 주소, 사업 기본 방향 및 체계, 사업 개요 및 세부계획, 추진사업 대상 위치 및 면적, 추진사업 실시예정 시기 및 기간, 재원조달계획 및 연차별 투자계획, 그 밖에 농촌융복합산업 추진에 필요한 
농림축산식품부령으로 정하는 사항을 포함하여야 한다.

\subsection{2 농촌융복합산업 사업자 인증 자격 요건 및 절차}

농촌융복합산업 인증사업자 선정을 위해서는 농업 관련 사업 주체여야 하고, 농촌에 입지해야 하며, 융복합 형태를 갖추는 등 [표 1]에서 제시한 자격요건을 갖추어야 한다.

[표 1] 농촌융복합산업 사업자 인증 자격요건

[Table 1] Requirements for Certification of Rural Convergence Industry Operators

\begin{tabular}{|c|c|}
\hline 구분 & 세부내용 \\
\hline 사업 주체 & $\begin{array}{l}\text { - 「농촌융복합산업법 제 } 2 \text { 조」에서 규정한 농업인, 농업법인, 농업관련 생산자단체·소상공인. } \\
\text { 사회적기업.협동조합 및 사회적 협동조합.중소기업·1인 창조기업 등 }\end{array}$ \\
\hline 사업장입지 & - 「농업·농촌 및 식품산업기본법 제3조제5호」에 규정된 농촌 지역 \\
\hline $\begin{array}{l}\text { 형태 및 } \\
\text { 주재료비율 }\end{array}$ & $\begin{array}{l}\text { - 농촌융복합형태: } 1 \text { 차 } \times 2 \text { 차 또는 } 1 \text { 차 } \times 3 \text { 차, } 1 \text { 차 } \times 2 \text { 차 } \times 3 \text { 차 } \\
\text { - 주원료는 자가생산 또는 계약재배 농산물(국산). 지역내 농산물 } 50 \% \text { 이상, 국산 } 100 \% \text { 사용 }\end{array}$ \\
\hline 사업성과 & - 최근 2년간 사업성과(매출액)가 있고, 평균 매출액‘최근 2 개년 평균 농가소득’달성 및 증빙 \\
\hline
\end{tabular}

농촌융복합산업 인증사업자 선정 심사는 [표 2]의 절차에 따라 실시하고 있다.

경영체는 인증신청 서류를 지역 농촌융복합산업지원센터에 제출하고, 지원센터는 심사 위원회를 구성하여 자격요건을 갖춘 신규.갱신 경영체 대상 서면·현장심사를 한다. 계획서는 적합성, 혁신성 및 경쟁력, 발전가능성, 지역농업 연계성, 사업성과 등에 따라 평가 후 70 점 이상을 시·도에 제출하고, 시·도는 「농촌융복합산업법」제 12 조에 따라 결격 사유가 없는 경영체를 한국농어촌공사에 제출한다. 한국농어촌공사는 추천된 사업 계획의 타당성 등을 평가하여 최종 적격자를 농식품부에 제출하며, 농식품부는 최종 적격자의 인증일을 지정하고, 시·도 및 지원센터에 인증 여부 통지 및 농촌융복합산업 인증서를 발급한다.

[표 2] 농촌융복합산업 사업자 인증 절차

[Table 2] Procedure for Certification of Rural Convergence Industry Operators

\begin{tabular}{|c|c|}
\hline $\begin{array}{l}\text { 진행 } \\
\text { 구진 }\end{array}$ & \begin{tabular}{l} 
(1)인증신청 \\
\cline { 2 - 3 } 옹촌융복합산업 \\
지원센터(시도)
\end{tabular} \\
\cline { 1 - 2 } & 인증신청 접수 \\
\hline
\end{tabular}

\begin{tabular}{|c|}
\hline (2)사업계획검토 \\
\hline $\begin{array}{c}\text { 농촌융복합산업 } \\
\text { 지원센터(시도) }\end{array}$ \\
\hline $\begin{array}{c}\text { 사업계획서 } \\
\text { 검토(서면·현장) }\end{array}$ \\
\hline
\end{tabular}

\begin{tabular}{|c|}
\hline (3)인증추천 \\
\hline $\begin{array}{c}\text { 농촌융복합산업 } \\
\text { 지원센터(시도) }\end{array}$ \\
\hline $\begin{array}{c}\text { 한국농어촌자원 } \\
\text { 개발원에 추천 }\end{array}$ \\
\hline
\end{tabular}

\begin{tabular}{|c|}
\hline (4)사업계획평가 \\
\hline $\begin{array}{c}\text { 한국농어촌공사 } \\
\text { (농자원) }\end{array}$ \\
\hline $\begin{array}{c}\text { 추천 대상자 } \\
\text { 사업계획 평가 }\end{array}$ \\
\hline
\end{tabular}

\begin{tabular}{|c|}
\hline (5)인증통지 \\
\hline 농식품부 \\
\hline $\begin{array}{c}\text { 인증 통지 } \\
\text { 인증서발급 }\end{array}$ \\
\hline
\end{tabular}

\subsection{3 농촌융복합산업 인증사업자 현황}

2019년 말 기준 전국 농촌융복합산업 인증사업자 수는 [표 3]과 같이 1,624개소이고, 이 중 충남은 172 개소이며, 15 개 시도 중 전북, 전남, 경북, 경기 순으로 인증사업자를 배출하고 있는 것을 알 수 있다. 
[표 3] 전국 농촌융복합산업 인증사업자 수 (2019)

[Table 3] The Number of Certified Rural Convergence Industry Operators in Republic of Korea (2019)

\begin{tabular}{|c|c|c|c|c|c|c|c|c|c|c|c|c|c|c|c|}
\hline 합계 & 전북 & 전남 & 경북 & 경기 & 충남 & 강원 & 경남 & 충북 & 제주 & 인천 & 세종 & 울산 & 광주 & 대구 & 대전 \\
\hline 1,624 & 251 & 249 & 204 & 177 & 172 & 158 & 139 & 116 & 97 & 29 & 22 & 6 & 2 & 2 & 0 \\
\hline
\end{tabular}

※ 인증사업자수(누적): ('15년) 802 개소 $\rightarrow$ ('16) $1,130 \rightarrow$ ('17) 1,397 $\rightarrow$ ('18) 1,524 $\rightarrow$ ('19) 1,624

2019년 말 기준 충남 농촌융복합산업 인증사업자는 [표 4]와 같이 172개소이며, 청양군이 가장 많은 18 개소이고, 공주, 금산, 논산, 부여가 각각 16 개소, 서산 15 개소 순으로 선정된 것을 확인할 수 있다[6].

[표 4] 충남 농촌융복합산업 인증사업자 수 (2019)

[Table 4] The Number of Certified Rural Convergence Industry Operators in Chungcheongnam-do (2019)

\begin{tabular}{|c|c|c|c|c|c|c|c|c|c|c|c|c|c|c|c|}
\hline 합계 & 청양 & 공주 & 금산 & 논산 & 부여 & 서산 & 예산 & 서천 & 아산 & 천안 & 태안 & 홍성 & 당진 & 보령 & 계룡 \\
\hline 172 & 18 & 16 & 16 & 16 & 16 & 15 & 14 & 13 & 10 & 10 & 8 & 8 & 7 & 3 & 2 \\
\hline
\end{tabular}

※ 인증사업자수(누적): ('15년) 64 개소 $\rightarrow$ ('16) $94 \rightarrow$ ('17) $127 \rightarrow$ ('18) $151 \rightarrow$ ('19) 172

\section{2 농촌융복합산업 지원정책 주요 성과지표}

본 연구에서 활용하고자 하는 매출액 증가율과 일자리 증가율이 사업성과 지표로서 대표성이 있는지 살펴보기 위해 2018년 「충남농촌융복합산업 종합발전 5개년 계획(2단 계)[28]」을 근거로 농촌융복합산업 지원정책의 주요 성과지표를 분석 후 [표 5]와 같이 정리하였다. 농촌융복합산업 지원정책 주요 성과지표는 매출액, 일자리, 원물 매입량, 참여농가 소득, 참여농가수, 방문객수 등을 사용하고 있으며, 12 개 사업 중 '매출액'을 성과지표로 하는 사업은 12 개(100\%)이고, '일자리'를 성과지표로 하고 있는 사업은 10 개 (83.3\%)로 농촌 융복합산업 성과지표로 대표성이 있는 것은 '매출액'과 '일자리'인 것을 확인할 수 있다. 농림축산식품부「제2차 농촌융복합산업 육성 및 지원 계획(2021 2025) 」의 성과지표는 매출액 증가율, 상시근로자수, 계약재배 비율이며[29], 농촌융복합산업 관련 지원정책의 대표적 성과지표도 '매출액 증가율'과 '일자리 증가율'이다. 이외에 성장단계의 구분지표로 매출액을 근거로 한 연구[30]와 필요인력 고용이 가능할 때 회계 관리, 마케팅이 가능해진다고 하여 일자리 중요성을 강조한 연구가 있다[21]. 따라서 본 연구에서 사용하고자 하는 연평균 매출액 증가율과 일자리 증가율은 사업성과 측정변인으로서 의미가 있다고 할 수 있다.

[표 5] 농촌융복합산업 지원정책 성과지표

[Table 5] Performance Indicators by Rural Convergence Industry Support Policy

\begin{tabular}{|c|c|c|c|c|c|c|c|c|c|c|c|c|c|c|}
\hline \multicolumn{2}{|c|}{ 구 분 } & $\begin{array}{l}\text { 지역전 } \\
\text { 략식품 }\end{array}$ & $\begin{array}{l}\text { 식품 } \\
\text { 소재 }\end{array}$ & $\begin{array}{c}\text { 농식품 } \\
\text { 가공 }\end{array}$ & $\begin{array}{l}\text { 전통 } \\
\text { 식품 }\end{array}$ & $\begin{array}{c}\text { 쌀가공 } \\
\text { 기업 }\end{array}$ & $\begin{array}{l}\text { 농식품 } \\
\text { 제조 }\end{array}$ & $\begin{array}{c}\text { 농촌 } \\
\text { 테마공 }\end{array}$ & $\begin{array}{l}\text { 농촌체 } \\
\text { 험휴양 }\end{array}$ & $\begin{array}{l}\text { 향토 } \\
\text { 산업 }\end{array}$ & $\begin{array}{l}\text { 농촌자 } \\
\text { 원복합 }\end{array}$ & $\begin{array}{c}\text { 농촌 } \\
\text { 융복합 }\end{array}$ & $\begin{array}{l}\text { 6차산 } \\
\text { 업지구 }\end{array}$ & $\begin{array}{c}\text { 지표 } \\
\text { 수 }\end{array}$ \\
\hline \multirow{2}{*}{$\begin{array}{l}\text { 원료 } \\
\text { 구입 }\end{array}$} & 매입량 & 0 & 0 & 0 & 0 & & 0 & & & o & & & & 6 \\
\hline & 매입액 & & 0 & & & & & & & O & & & & 2 \\
\hline
\end{tabular}




\begin{tabular}{|c|c|c|c|c|c|c|c|c|c|c|c|c|c|c|}
\hline \multirow{3}{*}{ 생산 } & 생산량 & & 0 & 0 & & & & & & & & & & 2 \\
\hline & 생산품목 & & 0 & 0 & & & & & & & & & & 2 \\
\hline & 가동률 & 0 & & & & & & & & & & & & 1 \\
\hline \multirow{2}{*}{ 수익 } & 매출액 & 0 & 0 & 0 & 0 & o & 0 & 0 & o & 0 & o & 0 & o & 12 \\
\hline & 수출액 & o & & & & 0 & & & & & o & & & 3 \\
\hline 고용 & 고용인원 & 0 & & 0 & 0 & 0 & 0 & 0 & & 0 & o & 0 & o & 10 \\
\hline \multirow{3}{*}{$\begin{array}{l}\text { 사업 } \\
\text { 참여 }\end{array}$} & 농가수 & 0 & & & 0 & & 0 & & & & o & & & 4 \\
\hline & 농가소득 & & & & & 0 & & 0 & & & o & 0 & o & 5 \\
\hline & 6차인증 & & & & & & & & & & & & 0 & 1 \\
\hline 방문객 & 방문객수 & & & & & & & 0 & & 0 & & 0 & 0 & 4 \\
\hline
\end{tabular}

\section{3. 연구 방법}

\section{1 분석대상 및 자료수집}

본 연구는 2019년 말 기준 충청남도 농촌융복합산업 인증사업자 중 2015년부터 2019년까지 매출액과 일자리의 기준을 모두 충족한 135개 사업자를 대상으로 하였고, 자료는 농림축산식품부와 충청남도의 협조를 받아 농촌융복합산업 인증사업자 관련 자료와 농촌 융복합산업 지원사업 관련 내부 행정자료를 수집한 후 분석에 사용하였다. 매출액 증가율은 충남 소재 135 개 인증사업자의 세무서 신고액을 기준으로 하였고, 일자리 증가율은 4대 보험 신고액 및 일용직 신고서류를 기준으로 하였다.

\section{2 변인선정}

본 연구의 종속변인은 충남 농촌융복합산업 인증사업자의 2015년부터 2019년까지 매출액 증가율과 일자리 증가율이다. 매출액 증가율과 일자리 증가율은 Z점수로 표준점수 화하여 분석에 사용하였으며, 표준화점수는 평균과 표준편차가 다른 두 실험그룹의 평균이 0 이고 표준편차가 1 인, 같은 분포상의 점수로 전환한 값으로 자료 간 상대적 위치를 알 수 있고, 평균과 표준편차가 다른 자료를 상호 비교할 수 있다.

농촌융복합산업 인증사업자의 매출액 증가율과 일자리 증가율의 표준점수화는 연도별 매출액과 일자리를 기준으로 연평균 증가율을 산출한 다음, 평균이 0 이고 표준편차가 1 인 Z표준화점수로 변환하였다. Z표준화점수 계산식은 아래와 같다.

$$
\mathrm{Z} \text { 표준화점수 }=\frac{(\text { 원점수 }- \text { 평균점수 })}{\text { 표준편차 }}
$$

선행연구에서는 인증사업자의 사업성과분석 변인으로 산업적기능유형, 주요작목, 농산 물가공유형, 서비스유형, 법인성격, 지역(도단위), 운영기간, 매출액, 직접생산율, 도내 생산비율로 설정한 사례[21]와 성별, 산업유형, 연령, 학력, 사업자형태, 판매처, 소득 수준 등을 기준으로 한 사례[1]와 성별, 연령, 영농경력, 귀농시기, 사업운영형태, 조직 형태, 사업차수, 가족농여부, 지역(도단위), 매출액으로 구분한 사례[22]가 있다. 
본 연구의 투입변수(독립변인)는 [표 6]과 같이 지역, 성별, 사업자형태, 융복합산업 유형, 보조사업 지원유무, 연령대, 운영기간으로 설정하였다. 융복합산업유형은 조사 대상 규모가 작은 $1 \times 2$ 차유형과 $1 \times 3$ 차유형을 '이외유형'으로 명명하여 $1 \times 2 \times 3$ 차형과 이외유형으로 구분하여 분석에 사용하였다.

\section{[표 6] 종속변인과 독립변인}

[Table 6] Dependent Variable and Independent Variable

\begin{tabular}{|c|c|c|c|c|}
\hline 집단구분 & \multicolumn{2}{|r|}{ 변 수 } & \multicolumn{2}{|r|}{ 변 수 } \\
\hline 종속변인 & 매출액증가율 & 2015 2019 매출액 연평균 증가율 & 일자리증가율 & 2015 2019 일자리 연평균 증가율 \\
\hline \multirow{4}{*}{ 독립변인 } & 시군 & 시(市)지역, 군(郡)지역 & 성별 & 남자, 여자 \\
\hline & 사업자형태 & 개인사업자, 법인사업자 & 보조사업지원 & 유(지원받음), 무(지원받지 않음) \\
\hline & 융복합유형 & $1 \times 2 \times 3$ 차형, 이외유형 & 연령대 & 40대 이하, 50 대, 60 대 이상 \\
\hline & 운영기간 & 5년 이하, 5년 10년, 10 년 초과 & & \\
\hline
\end{tabular}

\section{3 자료 분석 및 처리}

수집한 자료는 코딩, 오류수정, 보완을 거친 후 IBM SPSS Statistics 25 (IBM corp., Armonk, $\mathrm{NY}, \mathrm{USA})$ 를 활용하여 분석하였다. 통계적 방법에서 기술통계량은 빈도분석을 실시하였으며, 인증사업자 특성 중 지역, 성별, 사업자형태, 융복합유형, 보조사업 지원 유무에 따른 사업성과 분석은 T-test를 실시하였고, 연령대와 운영기간은 One-Way ANOVA 검정을 실시하였다. 운영기간에 따른 사업성과에 대해 그룹간 차이 분석을 위해 Duncan Test(LDS)를 실시하였다.

\section{4. 연구결과}

\section{1 연구대상자의 일반적 특성}

\subsection{1 일반적 특성}

연구대상자의 일반적 특성은 지역, 성별, 사업자형태, 융복합유형, 보조사업지원유무, 연령대, 운영기간, 매출액과 일자리 증가율이 조사되었고 자료 분포는 [표 7]과 같다.

지역은 시 63 개(46.7\%), 군 72 개(53.5\%)로 비슷한 비율을 보였고, 성별은 남성 92 명 $(68.1 \%)$, 여성 43 명 $(31.9 \%)$ 으로 남성이 다소 높게 조사되었다. 사업자형태는 개인 사업자 43 개 $31.1 \%)$, 개인사업자를 제외한 법인사업자 93개(68.9\%)로 법인사업자 비율이 높았다. 융복합유형은 $1 \times 2 \times 3$ 차형 96 개(71.1\%), 이외유형 39 개(28.9\%)로 대부분 $1 \times 2 \times 3$ 차형으로 조사되었고, 보조사업 지원은 유 64 개소 $(47.4 \%)$, 무 71 개소 $(52.6 \%)$ 로 비슷한 분포를 보였다. 연령대는 40 대 이하 37명(27.4\%), 50대 56명(41.5\%), 60대 이상 42명 $(31.1 \%)$ 으로 50 대가 가장 많은 분포를 보였으며, 이는 50 대가 퇴직 후 경제활동을 위해 사업에 참여하면서 증가한 것으로 판단된다. 운영기간은 5년 이하 26 개소(19.3\%), 5년 10 년 63 개소(46.7\%), 10 년 초과 46 개소(34.1\%)로 5년 10년 경영체 비중이 가장 높았 으며, 농촌융복합산업이 본격화된 2013년 이후 기존사업을 농촌융복합 산업으로 전환하거나 창업한 것이 주요 요인으로 보인다. 매출액 증가율은 감소 32 개소 $(23.7 \%)$, 증가 103 개소(76.3\%)로 증가비율이 높은 것으로 조사되었고, 일자리 증가율은 감소 28 개소 
(20.7\%), 증가 107 개소(79.3\%)로 매년 새로운 일자리를 창출하고 있는 경영체의 비중이 높은 것을 알 수 있다.

[표 7] 충남 농촌융복합산업 인증 사업자의 일반적 특성

[Table 7] General characteristics of Certified Regular Convergence Industry Operators in Chungnam

\begin{tabular}{|c|c|c|c|c|c|c|c|}
\hline \multicolumn{2}{|c|}{ 변 인 } & 빈도(업체수) & 백분율(\%) & \multicolumn{2}{|c|}{ 변 인 } & 빈도(업체수) & 백분율(\%) \\
\hline \multirow{2}{*}{ 지역(시군) } & 시지역(7) & 63 & 46.7 & \multirow{2}{*}{ 성별 } & 남자 & 92 & 68.1 \\
\hline & 군지역(8) & 72 & 53.3 & & 여자 & 43 & 31.9 \\
\hline \multirow{2}{*}{ 사업자형태 } & 개인사업자 & 42 & 31.1 & \multirow{2}{*}{ 융복합유형 } & 이외유형 & 39 & 28.9 \\
\hline & 법인사업자 & 93 & 68.9 & & $1 \times 2 \times 3$ 차형 & 96 & 71.1 \\
\hline \multirow{2}{*}{$\begin{array}{l}\text { 보조사업 } \\
\text { 지원유무 }\end{array}$} & 유 & 64 & 47.4 & \multirow{2}{*}{$\begin{array}{l}\text { 일자리 } \\
\text { 증가율 }\end{array}$} & 감소 & 28 & 20.7 \\
\hline & 무 & 71 & 52.6 & & 증가 & 107 & 79.3 \\
\hline \multirow{3}{*}{$\begin{array}{l}\text { 경영체 } \\
\text { 운영기간 }\end{array}$} & 5년 이하 & 26 & 19.3 & \multirow{3}{*}{$\begin{array}{l}\text { 대표자 } \\
\text { 연령대 }\end{array}$} & 40대 이하 & 37 & 27.4 \\
\hline & 5년 10년 & 63 & 46.7 & & 50대 & 56 & 41.5 \\
\hline & 10년 초과 & 46 & 34.1 & & 60대 이상 & 42 & 31.1 \\
\hline \multirow{2}{*}{$\begin{array}{l}\text { 매출액 } \\
\text { 증가율 }\end{array}$} & 감소 & 32 & 23.7 & & & & \\
\hline & 증가 & 103 & 76.3 & & & & \\
\hline
\end{tabular}

이상의 결과에서 충청남도 농촌융복합산업 인증사업자는 경력 5 년 10 년, 법인사업자, 50 대, $1 \times 2 \times 3$ 차형의 비율이 높고, 매출액과 일자리가 증가하는 경영체 비중이 높은 것으로 확인되었다. 충북의 인증경영체 대상 연구에서 개인사업자보다 법인사업자가 $73.4 \%$ 로 비중이 높고, $1 \times 2 \times 3$ 차형이 $90.3 \%$ 로 높은 비율을 보였으며, 2015년부터 2018년까지 인증경영체의 매출이 지속 증가하고 있어 본 연구와 유사한 경향을 보이고 있으나 일자리는 2015년 대비 2018년 대폭 감소한 것으로 조사되어 충남의 현황과는 다소 차이가 있었으며, 이는 인건비 절감 및 기계식 생산 증가의 영향으로 해석하고 있다[1].

\subsection{2 인증사업자 특성별 최근 5년간 매출액과 일자리 현황}

인증사업자 특성에 따른 최근 5년간 매출액과 일자리 현황은 [표 8]과 같다.

경영체의 최근 5년간 평균 매출액은 2015년 983.8백만원, 2016년 1,245.9백만원, 2017 년 1,265.3백만원, 2018년 1,380.8백만원, 2019년 1,446.1백만원으로 2015년에 비해 2019년 1.47 배로 증가하였고, 해마다 지속 증가한 것으로 확인된다. 인증경영체의 최근 5 년간 평균 일자리는 2015년 10.2명, 2016년 11.0명, 2017년 11.5명, 2018년 11.8명, 2019년 11.9명으로 2015년 대비 2019년에는 1.17배 증가하였고, 해마다 지속 증가한 것으로 확인되어 충남 인증사업자의 연간 평균 매출액과 일자리는 매년 증가하고 있는 것을 알 수 있다.

[표 8] 인증사업자 특성별 최근 5년간 매출액 및 일자리 현황

[Table 8] Current Status of Sales Over the Past 5 Years by Characteristics of Certified Busicess Operators

\begin{tabular}{|c|c|c|c|c|c|c|c|c|c|c|c|c|}
\hline \multirow{2}{*}{\multicolumn{2}{c|}{ 변 인 }} & \multirow{3}{*}{ 빈도 } & \multicolumn{5}{|c|}{ 매출액(백만원) } & \multicolumn{4}{c|}{ 일자리(명) } \\
\cline { 4 - 14 } & & & 2015 & 2016 & 2017 & 2018 & 2019 & 2015 & 2016 & 2017 & 2018 & 2019 \\
\hline \multirow{3}{*}{ 시군 } & 시지역(7) & 63 & 980.8 & $1,241.0$ & $1,256.0$ & $1,371.6$ & $1,436.5$ & 10.5 & 11.3 & 11.8 & 12.1 & 12.2 \\
\cline { 2 - 14 } & 군지역(8) & 72 & 983.7 & $1,245.9$ & $1,265.3$ & $1,380.8$ & $1,446.1$ & 10.2 & 11.0 & 11.5 & 11.8 & 11.9 \\
\hline
\end{tabular}




\begin{tabular}{|c|c|c|c|c|c|c|c|c|c|c|c|c|}
\hline \multirow{2}{*}{ 성별 } & 남자 & 92 & 977.0 & $1,244.0$ & $1,261.8$ & $1,376.5$ & $1,440.3$ & 10.4 & 11.2 & 11.7 & 12.0 & 12.1 \\
\hline & 여자 & 43 & 990.1 & $1,254.2$ & $1,273.8$ & $1,390.1$ & $1,455.8$ & 10.3 & 11.1 & 11.6 & 11.9 & 11.9 \\
\hline \multirow{2}{*}{$\begin{array}{l}\text { 사업자 } \\
\text { 형태 }\end{array}$} & 개인사업자 & 42 & 988.8 & $1,262.9$ & $1,274.5$ & $1,392.0$ & $1,458.2$ & 10.1 & 10.8 & 11.2 & 11.6 & 11.8 \\
\hline & 법인사업자 & 93 & 977.0 & $1,244.0$ & $1,261.8$ & $1,376.5$ & $1,440.3$ & 10.4 & 11.2 & 11.7 & 12.0 & 12.1 \\
\hline \multirow{2}{*}{$\begin{array}{l}\text { 융복합 } \\
\text { 유형 }\end{array}$} & 이외(1×2차, $1 × 3$ 차) & 39 & 983.7 & $1,245.9$ & $1,265.3$ & $1,380.8$ & $1,446.1$ & 10.2 & 11.0 & 11.5 & 11.8 & 11.9 \\
\hline & $1 \times 2 \times 3$ 차융복합 & 96 & 985.3 & $1,247.9$ & $1,263.7$ & $1,379.7$ & $1,444.0$ & 10.6 & 11.4 & 11.8 & 12.2 & 12.2 \\
\hline \multirow{2}{*}{$\begin{array}{l}\text { 보조사업 } \\
\text { 지원유무 }\end{array}$} & 유 & 64 & 983.5 & $1,252.5$ & $1,270.4$ & $1,386.0$ & $1,450.2$ & 10.4 & 11.3 & 11.7 & 12.1 & 12.1 \\
\hline & 무 & 71 & 983.7 & $1,245.9$ & $1,265.3$ & $1,380.8$ & $1,446.1$ & 10.2 & 11.0 & 11.5 & 11.8 & 11.9 \\
\hline \multirow{3}{*}{ 연령대 } & 40대 이하 & 37 & 995.4 & $1,282.9$ & $1,289.3$ & $1,408.3$ & $1,467.2$ & 10.4 & 11.1 & 11.6 & 11.9 & 12.1 \\
\hline & 50 대 & 56 & 969.7 & $1,237.9$ & $1,257.7$ & $1,375.3$ & $1,438.2$ & 10.3 & 11.1 & 11.6 & 12.0 & 12.0 \\
\hline & 60대 이상 & 42 & 990.1 & $1,254.2$ & $1,273.8$ & $1,390.1$ & $1,455.8$ & 10.3 & 11.1 & 11.6 & 11.9 & 11.9 \\
\hline \multirow{3}{*}{ 운영기간 } & 5년 이하 & 26 & 985.7 & $1,245.6$ & $1,259.8$ & $1,376.4$ & $1,441.9$ & 10.4 & 11.1 & 11.5 & 11.8 & 12.0 \\
\hline & 5년초과 10년이하 & 63 & 963.1 & $1,228.9$ & $1,248.8$ & $1,365.8$ & $1,427.9$ & 10.2 & 11.0 & 11.5 & 11.9 & 11.9 \\
\hline & 10 년 초과 & 46 & 999.1 & $1,265.2$ & $1,283.8$ & $1,402.1$ & $1,467.5$ & 10.3 & 10.9 & 11.3 & 11.7 & 11.9 \\
\hline \multicolumn{3}{|c|}{ 평균 } & 983.7 & $1,245.9$ & $1,265.3$ & $1,380.8$ & $1,446.1$ & 10.2 & 11.0 & 11.5 & 11.8 & 11.9 \\
\hline
\end{tabular}

\section{2 인증사업자 특성에 따른 사업성과}

\subsection{1 인증사업자 특성별 사업성과}

인증사업자의 지역과 성별에 따른 매출액과 일자리 증가율 분석결과는 [표 9]와 같다.

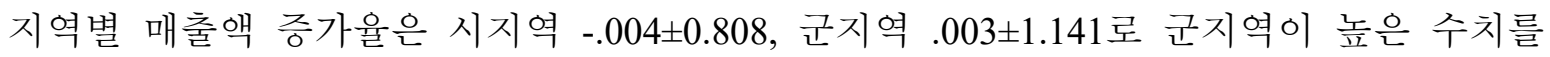
보였고, 일자리 증가율은 시지역 $.054 \pm 0.957$, 군지역 $-.048 \pm 1.041$ 로 시지역이 다소 높은 수치를 보였으나, 모두 통계적으로 유의미한 차이는 없었다. 시지역 매출액 증가율은 음(-)이나 일자리 증가율은 양(+)이고, 군지역 매출액 증가율은 양 $(+)$ 이나 일자리 증가율은 음(-)인 것은 군지역 경영 규모가 시지역에 비해 크지 않고 가족경영 중심으로 무보수로 경영에 참여하면서 고용에 의한 지출을 줄이면서 나타난 결과로 해석된다. 성별에 따른 분석결과 매출액 증가율은 남성 $-.010 \pm 0.812$, 여성 $.020 \pm 1.327$, 일자리 증가율은 남성 $-.059 \pm 0.962$, 여성 $.130 \pm 1.080$ 로 남성이 상대적으로 낮은 수치를 보였으나, 통계적으로 유의미한 차이는 보이지 않았다.

[표 9] 지역과 성별에 따른 사업성과

[Table 9] Business Performance by Region and Sex

\begin{tabular}{|c|c|c|c|c|c|c|c|}
\hline 변인 & 종속변수 & 독립변수 & 빈도 & 평균 & 표준편차 & $\mathrm{t}$ & 유의확률 \\
\hline \multirow{4}{*}{$\begin{array}{c}\text { 지역 } \\
\text { (사업장소재지) }\end{array}$} & \multirow{2}{*}{$\begin{array}{l}\text { 매출액 } \\
\text { 증가율 }\end{array}$} & 시지역 & 63 & -.004 & .818 & \multirow{2}{*}{-.041} & \multirow{2}{*}{.967} \\
\hline & & 군지역 & 72 & .003 & 1.141 & & \\
\hline & \multirow{2}{*}{$\begin{array}{l}\text { 일자리 } \\
\text { 증가율 }\end{array}$} & 시지역 & 63 & .054 & .957 & \multirow{2}{*}{.590} & \multirow{2}{*}{.556} \\
\hline & & 군지역 & 72 & -.048 & 1.041 & & \\
\hline \multirow{4}{*}{ 성별 } & \multirow{2}{*}{$\begin{array}{l}\text { 매출액 } \\
\text { 증가율 }\end{array}$} & 남성 & 92 & -.010 & .812 & \multirow{2}{*}{-.161} & \multirow{2}{*}{.872} \\
\hline & & 여성 & 43 & .020 & 1.327 & & \\
\hline & \multirow{2}{*}{$\begin{array}{l}\text { 일자리 } \\
\text { 증가율 }\end{array}$} & 남성 & 92 & -.059 & .962 & \multirow{2}{*}{-.1016} & \multirow{2}{*}{.311} \\
\hline & & 여성 & 43 & .130 & 1.080 & & \\
\hline
\end{tabular}


인증사업자의 사업자형태와 융복합유형, 보조사업에 따른 사업성과는 [표 10]과 같다.

사업자형태에서 매출액 증가율은 개인사업자 .011 \pm 1.233 , 법인사업자 $-.005 \pm 0.883$ 으로 개인사업자가 높은 수치를 보였고, 일자리 증가율은 개인사업자 $-.093 \pm 0.856$, 법인사업자 $.041 \pm 1.059$ 로 개인사업가가 낮은 수치를 보였으나, 통계적으로 유의미한 차이는 없었다. 선행연구에서도 사업자형태는 사업성과에 영향을 주는 요인이 아니라고 하였으며[21], 개인사업자의 매출액 증가율이 양 $(+)$ 이나 일자리 증가율은 음(-)을 보인 것은 대표가 무보수로 경영에 참여하면서 나타난 결과로 해석된다.

융복합유형에서 매출액 증가율은 이외유형 .071 $\pm 1.231,1 \times 2 \times 3$ 차형 $\quad-.029 \pm 0.987$ 로 이외유형이 높은 수치를 보였고, 일자리 증가율은 이외유형 $-.004 \pm 0.748, \quad 1 \times 2 \times 3$ 차 형 .002 \pm 1.090 으로 이외유형이 낮게 분석되었으나, 통계적으로 유의미한 차이는 없었다. 이외유형의 매출액 증가율이 양 $(+)$ 이나 일자리 증가율은 음(-)인 것 또한 이외유형 대표가 무보수로 경영에 참여하면서 나타난 결과로 보인다.

보조사업지원유무에서 매출액 증가율은 유 $-.105 \pm 0.673$, 무 $.094 \pm 1.220$, 일자리 증가율은 유 $-.012 \pm 0.821$, 무 $.011 \pm 1.145$ 로 보조사업을 지원받은 경우가 모두 낮게 분석되었으나 통계적으로 유의미한 차이는 없었다. 보조사업을 지원받은 경우 매출액 증가율과 일자리 증가율이 음(-)으로 나타난 것은 보조사업 추진을 위한 자부담액과 사업 확대를 위한 운영비 지출이 늘어나면서 매출 규모가 줄어든 것으로 보이며, 고용을 줄이고 운영비를 마련하는 등으로 인해 일자리의 규모도 줄어든 것으로 해석된다. 이 경우는 보조사업 지원 후 연차별 사업성과에 대한 지속적인 모니터링과 컨설팅으로 사업 활성화 및 내실화를 도모해야 할 것으로 판단된다.

[표 10] 사업자 형태와 융복합 유형, 보조사업 지원유무별 사업성과

[Table 10] Business Performance by Business Type, Convergence Type and Subsidiary Project

\begin{tabular}{|c|c|c|c|c|c|c|c|}
\hline 변인 & 종속변수 & 독립변수 & 빈도 & 평균 & 표준편차 & $\mathrm{t}$ & 유의확률 \\
\hline \multirow{4}{*}{ 사업자 형태 } & \multirow{2}{*}{$\begin{array}{l}\text { 매출액 } \\
\text { 증가율 }\end{array}$} & 개인 & 42 & .011 & 1.233 & \multirow{2}{*}{.084} & \multirow{2}{*}{.934} \\
\hline & & 법인 & 93 & -.005 & .883 & & \\
\hline & \multirow{2}{*}{$\begin{array}{l}\text { 일자리 } \\
\text { 증가율 }\end{array}$} & 개인 & 42 & -.093 & .856 & \multirow{2}{*}{-.712} & \multirow{2}{*}{.478} \\
\hline & & 법인 & 93 & .041 & 1.059 & & \\
\hline \multirow{4}{*}{ 융복합 유형 } & \multirow{2}{*}{$\begin{array}{l}\text { 매출액 } \\
\text { 증가율 }\end{array}$} & 이외 유형 & 39 & .071 & 1.231 & \multirow{2}{*}{.522} & \multirow{2}{*}{.603} \\
\hline & & $1 \times 2 \times 3$ 차형 & 96 & -.029 & .987 & & \\
\hline & \multirow{2}{*}{$\begin{array}{l}\text { 일자리 } \\
\text { 증가율 }\end{array}$} & 이외 유형 & 39 & -.004 & .748 & \multirow{2}{*}{-.029} & \multirow{2}{*}{.977} \\
\hline & & $1 \times 2 \times 3$ 차형 & 96 & .002 & 1.090 & & \\
\hline \multirow{4}{*}{$\begin{array}{l}\text { 보조사업 } \\
\text { 지원유무 }\end{array}$} & \multirow{2}{*}{$\begin{array}{l}\text { 매출액 } \\
\text { 증가율 }\end{array}$} & 유(지원 있음) & 64 & -.105 & .673 & \multirow{2}{*}{-1.191} & \multirow{2}{*}{.236} \\
\hline & & 무(지원 없음) & 71 & .094 & 1.220 & & \\
\hline & \multirow{2}{*}{$\begin{array}{l}\text { 일자리 } \\
\text { 증가율 }\end{array}$} & 유(지원 있음) & 64 & -.012 & .821 & \multirow{2}{*}{-.134} & \multirow{2}{*}{.893} \\
\hline & & 무(지원 없음) & 71 & .011 & 1.145 & & \\
\hline
\end{tabular}

인증사업자의 연령대와 운영기간에 따른 사업성과는 [표 11]과 같다.

연령대별 매출액 증가율은 40 대 이하 $.079 \pm 0.892,50$ 대 $-.024 \pm 1.122,60$ 대 이상 $-.037 \pm 0.935$ 로 40 대 이하가 가장 높게 나타났고, 연령대별 일자리 증감률은 40 대 
이하 $.037 \pm 0.933,50$ 대 $-.105 \pm 0.898,60$ 대 이상 $.110 \pm 1.185$ 로 60 대 이상이 가장 높게 분석되었으나, 통계적으로 유의미한 차이는 보이지 않았다.

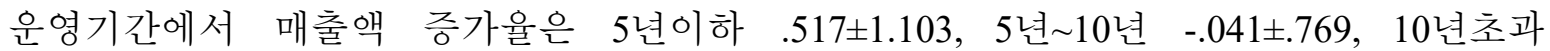
$-.236 \pm 1.128$ 로 5 년 이하가 가장 높았으며, 통계적으로 $\mathrm{F}=5.108$, 유의확률 .007 로 유의미한 영향이 있는 것으로 분석되었다 $(\mathrm{p}<0.05)$. 이와 같은 결과에서 운영기간의 그룹간 매출액 증가율은 적어도 어느 두 그룹 간에는 유의미한 차이가 있다고 할 수 있다. 운영 기간에

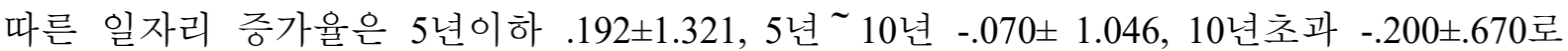
5 년 이하가 가장 높았으나 통계적으로 유의미한 차이는 없었다.

선행연구에서 운영기간은 사업성과에 영향을 주는 변인이 아니라고 하였으나[21], 대규모 경영체의 경영 규모가 클수록 운영기간이 비교적 긴 것으로 조사되어 운영기간은 1 차와 2 차, 3 차 산업 추진에 대한 역량을 보여주는 것으로서 경영규모에 영향을 미치는 요소가 될 수 있는 것으로 판단하였다.

결과적으로 농촌융복합산업 인증사업자의 지역, 성별, 사업자형태, 융복합유형, 보조 사업 지원유무, 연령대는 매출액 증가율과 일자리 증가율에 통계적으로 유의미한 영향을 미치지 않는 것으로 확인되었고, 운영기간에서 일자리 증가율은 유의미한 차이가 없는 것으로 조사되었으나, 매출액 증가율은 통계적으로 유의미한 결과가 있는 것으로 분석되었다 $(\mathrm{p}<0.05)$.

[표 11] 연령대와 운영기간별 사업성과

[Table 11] Business Performance by Age Group and Operating Period

\begin{tabular}{|c|c|c|c|c|c|c|c|}
\hline 변인 & 종속변수 & 독립변수 & 빈도 & 평균 & 표준편차 & $\mathrm{F}$ & 유의확률 \\
\hline \multirow{6}{*}{ 연령대 } & \multirow{3}{*}{$\begin{array}{l}\text { 매출액 } \\
\text { 증가율 }\end{array}$} & 40대 이하 & 37 & .079 & .892 & \multirow{3}{*}{.159} & \multirow{3}{*}{.853} \\
\hline & & 50대 & 56 & -.024 & 1.122 & & \\
\hline & & 60대 이상 & 42 & -.037 & .935 & & \\
\hline & \multirow{3}{*}{$\begin{array}{l}\text { 일자리 } \\
\text { 증가율 }\end{array}$} & 40대 이하 & 37 & .037 & .933 & \multirow{3}{*}{.582} & \multirow{3}{*}{.560} \\
\hline & & 50대 & 56 & -.105 & .898 & & \\
\hline & & 60대 이상 & 42 & .110 & 1.185 & & \\
\hline \multirow{6}{*}{ 운영기간 } & \multirow{3}{*}{$\begin{array}{l}\text { 매출액 } \\
\text { 증가율 }\end{array}$} & 5년 이하 & 26 & .517 & 1.103 & \multirow{3}{*}{5.108} & \multirow{3}{*}{$.007 *$} \\
\hline & & 5년 10년 & 63 & -.041 & .769 & & \\
\hline & & 10년 초과 & 46 & -.236 & 1.128 & & \\
\hline & \multirow{3}{*}{$\begin{array}{l}\text { 일자리 } \\
\text { 증가율 }\end{array}$} & 5년 이하 & 26 & .192 & 1.321 & \multirow{3}{*}{1.545} & \multirow{3}{*}{.217} \\
\hline & & 5년 10년 & 63 & .070 & 1.046 & & \\
\hline & & 10년 초과 & 46 & -.200 & .670 & & \\
\hline
\end{tabular}

${ }^{*} \mathrm{p}<0.05$

운영기간에 따른 인증경영체의 연평균 매출액 증가율에 대해 그룹간 비교 분석을 위해 사후검정을 실시한 결과는 [표 12]와 같다. 그룹간 분석결과, 5 년 이하 그룹에 대해 5년 10년 그룹, 10 년초과 그룹간의 평균차이는 $\mathrm{p}<0.05$ 에서 유의미한 차이가 있는 것으로 확인되었으며, 운영기간이 길수록 그룹의 매출액 증가율이 높은 경향을 보이는 것을 알 수 있다. 
[표 12] 운영기간별 매출액 증가율에 대한 사후검정(LSD)

[Table 12] Duncan Test(LSD) for Sales Growth Rate by Operating Period

\begin{tabular}{|c|c|c|c|}
\hline 운영기간(I) & 운영기간(J) & 평균차이(I-J) & 유의확률 \\
\hline \multirow{2}{*}{ 5년 이하 } & 5년 10년 & .559 & $0.015^{*}$ \\
\cline { 2 - 4 } & 10년 초과 & .753 & $0.002^{*}$ \\
\hline \multirow{2}{*}{5 년 10년 } & 5년 이하 & -.559 & $0.015^{*}$ \\
\cline { 2 - 4 } & 10년 초과 & 0.196 & 0.301 \\
\hline \multirow{2}{*}{ 10년 초과 } & 5년 이하 & -.753 & $0.002 *$ \\
\cline { 2 - 4 } & 5년 10년 & -0.196 & 0.301 \\
\hline
\end{tabular}

${ }^{*} \mathrm{p}<0.05$

선행연구에서 운영 기간은 매출액에 영향을 주는 변수는 아니라고 하였으나 매출액 규모가 클수록 운영 기간이 비교적 긴 것으로 조사되어, 매출액 규모에 따른 운영 기간은 차이가 있다고 하였고[21], 충남 농촌산업 정부지원사업 지원 경영체의 재무제표를 분석한 연구에서도 농업법인의 매출액과 영업이익률, 당기순이익이 증가하고 있는 경영체 비율이 높고, 전체 기업 재무비율 기술통계 결과 6차산업이 고용창출 유발효과가 있다고 하였으며, 경영체 중 농촌융복합산업 인증사업자가 상대적으로 효율성이 높고[18], 매출액이 높은 집단이 사업 채택률과 정보 획득력이 높으며, 사업포기 또는 지체정도가 낮아 인증업체의 고른 기회 제공을 위한 심사방식 개선, 사업정책 확대, 우수업체와 영세업체 간 상생협력 필요성 등을 강조하였다[24].

결과적으로 농촌융복합산업 인증사업자는 사업 초반에 매출액 증가율이 크게 상승하고, 운영 기간이 길수록 매출액 증가율이 높아지는 것으로 파악되었다. 이는, 경영체의 운영 기간이 길어질수록 대표자 및 사업체의 경영기술 역량이 사업 초반보다 향상되면서 생산성, 수익성, 성장성, 효율성이 개선됨으로 인해 경영체의 매출액에 직간 접적으로 영향을 미치는 것으로 판단된다. $\mathrm{DEA}$ 효율성 분석을 위해 $\mathrm{BCC}$ 모형을 적용한 선행연구에서도 타사업지원 경영체보다 농촌융복합산업 인증사업 경영체가 효율성이 가장 높다고 하였고, 이는 농촌융복합산업 인증사업자에 대한 우수제품 판로확대, 홍보지원, 저금리 대출 등의 지원으로 인한 것이라고 판단하였다[18].

\section{5. 결론}

본 연구의 목적은 충남 농촌융복합산업 인증사업자의 사업성과를 분석하고 발전 방안을 제안하는 것이다. 이를 위해 충남 농촌융복합산업 인증사업자 135 개소를 대상으로 2015년부터 2019년까지 사업운영 성과를 살펴보았으며, 주요 분석 결과는 다음과 같다.

첫째, 충남 농촌융복합산업 인증사업자는 5 년 10 년 경력, 법인사업자, 50 대, $1 \times 2 \times 3$ 차형 비율이 높고, 매출액과 일자리가 증가하는 경영체의 비중이 높은 것으로 확인되었다. 이는 매출액과 일자리가 사업운영 성과 및 재인증 평가 기준이 되면서 인증 경영체가 성과 도출을 위해 지속적으로 노력한 성과로 보이며, 인증경영체에 대한 정부 및 지자체의 판로 및 홍보지원, 저금리 융자 지원 등이 긍정적인 영향을 미치는 것으로 판단되어 관련 정책이 지속적으로 유지 및 강화될 필요가 있는 것으로 확인되었다. 둘째, 사업장 소재지는 매출액과 일자리 증가율에 유의적인 영향을 미치지 않는 것으로 
분석되었다. 군지역의 경우 매출액 증가율은 양 $(+)$ 이나 일자리 증가율은 음(-)의 값으로 조사되어 사례 검토 결과 소규모 경영체의 가족 중심 경영으로 일자리 증가율이 감소한 반면 $1 \times 2 \times 3$ 차형 운영으로 원물의 직접 생산, 2 차 단순 가공과 3 차 체험 운영 등 농촌 자원의 다원적 가치 활용 등 내실 있는 사업 경영이 매출액 증가로 이어진 것으로 확인되었다. 이 경우 향후 사업 확대를 위한 대규모 시장 공략의 중장기적 접근이 필요할 것으로 판단된다. 셋째, 농촌융복합유형은 매출액과 일자리 증가율에 유의한 영향을 미치지 않는 것으로 분석되었고, 이외유형 $(1 \times 2$ 차형, $1 \times 3$ 차형 $)$ 에서 매출액 증가율은 양 $(+)$ 이나 일자리 증가율은 음(-)으로 조사되었다. 이는 대표의 무보수 경영으로 인건비 지출 규모 최소화, 가공중심형 대규모형( 10 억 이상) 경영체의 매출액 증가 기여, 체험 중심형 경영체의 체험상품 소비시장 확대 등으로 인해 나타난 결과로 해석되나 구체적인 원인은 세부 특성간 비교 검토가 추가연구를 통해 밝혀질 필요가 있을 것으로 판단된다. 넷째, 보조사업을 지원받은 경영체 매출액과 일자리 증가율이 모두 음(-)으로 조사되었 다. 이는 보조사업 추진을 위한 자부담 지출과 사업 확대를 위한 운영비 지출 증가, 사업규모 확대기간 동안의 사업 경영 중단 또는 집중 부족 등으로 매출 규모가 줄어든 것으로 판단되며, 매출이 줄어들면서 고용을 줄이고 사업 운영자금을 마련하는 등의 자구책으로 일자리 증가율이 감소한 것으로 해석된다. 내실 있는 보조사업 운영을 위해서는 사전 준비가 철저히 이루어질 필요가 있고, 보조사업 지원 후 사업성과 관련 지속 모니터링과 컨설팅으로 사업 활성화와 내실화가 필요한 것이 확인되었다. 다섯째, 운영 기간은 일자리 증가율에 유의한 영향을 미치지 않았으나 매출액 증가율에 유의한 영향을 미치는 것으로 조사되었고, 5년이하의 매출액 증가율이 가장 높은 것으로 분석되었다 $(\mathrm{p}<0.05)$. 매출액 증가율에 대해 그룹간 사후검정(LSD) 결과 5 년 이하 그룹에 대해 5 10년 그룹과 10 년 초과 그룹간의 평균 차이는 $\mathrm{p}<0.05$ 에서 유의미한 차이가 있는 것으로 분석되어 운영 기간이 길수록 매출액 증가율은 높은 경향을 보이는 것으로 확인되었다. 농촌융복합산업 인증사업자의 사업 운영 기간은 1 차와 2 차, 3 차 산업 추진에 대한 역량을 통한 경영 내실화를 보여주는 중요한 성과지표로 판단된다.

본 연구의 주요 시사점은 첫째, 인증경영체의 운영 기간이 길수록 경영체의 매출액은 증가하고 특히 사업 초반(5년 이하)에 인증사업자의 매출액 상승 폭이 매우 큰 것으로 확인되면서 운영 기간이 사업 내실화의 지표가 될 수 있음을 밝힌 것이다. 둘째, 보조 사업 지원 경영체의 보다 체계적이고 내실 있는 사업 추진을 위한 지속적인 모니터링과 컨설팅 등 전주기적 지원 관리 강화와 해당 경영체가 지속 성장하는 사업체로 자립화 할 수 있는 활성화 방안의 필요성이 제안된 것이다.

농촌융복합산업 인증사업자에 대한 정책 지원방안으로 첫째, 경영 연수가 늘어남에 따라 경영 노하우 축적이 이루어지므로 경영체 역량강화를 위한 필수역량강화교육이 필요하다. 둘째, 사업 지속성을 위한 맞춤형 전문가 컨설팅지원, 핵심인재가 지속 근무 할 수 있는 여건 조성이 필요하다. 셋째, 인증받은 사업자에 대해 성장단계별 맞춤형 정책 지원을 내실화하여 지역사회에 지도자로서의 역할을 강화할 필요가 있다.

농촌융복합산업 활성화를 위해서는 농촌융복합산업 전담조직 구성과 중간지원 조직의 전문성 강화와 농가 및 경영체의 농촌융복합산업 정책 접근성 확대를 위한 시스템 구축 이 필요하며, 시군 담당공무원 전문성 강화, 경영체 맞춤형 교육프로그램 운영, 웹 기반 실시간 화상 클래스 플랫폼 구축이 필요하고, 거점형 위탁가공시설 구축, 곤충산업 및 반려동물산업, 고령친화식품 등의 신성장 산업기반조성, 치유, 힐링 등 신규아이템 활용 체험프로그램 개발이 필요하다. 또한 온라인 판매 활성화, 농업과 식품외식산업 동반 
성장 도모, 유통채널 개척 지원, 수출 전반에 대한 종합적인 지원이 검토되어야 한다.

본 연구에서는 농촌융복합산업 인증사업자의 일반적 특성을 그룹화하여 사업성과 분석을 하였으나 일반적 특성 간의 밀도 있는 분석으로 보다 내실 있는 경영성과 도출 및 개선방안이 제안되어야 할 것이며, 충청남도뿐만 아니라 전국적인 데이터로 대표성 있는 연구결과를 제안할 수 있도록 개선될 필요가 있다.

\section{References}

[1] J. M. Woo, S. W. Lee, H. S. Kim, Current Status and Promotion Plan of Certified Management of Rural Convergence Industry in Chungbuk, Chungbuk FOCUS, (2019), Vol.9, No.169, pp.1-26.

[2] https://www.6차산업.com:448/home/sub.cs?m=11, Sept 22 (2021)

[3] S. H. Kim, K. Suh, J. Y. Park, S. W. Lee, J. B. Jeon, How Government Policy Directions lead Rural Development Projects, Journal of Korean Society of Rural Planning, (2020), Vol.26, No.1, pp.123-136, DOI: 10.7851/ Ksrp.2020.26.1.123

[4] Korea Rural Economic Institute, A 4th Study on the Establishment of Basic Plan for Improving the Quality of Life of Agricultural and Fishery Workers, Ministry of Agriculture, Food and Rural Affairs, pp.34-40, (2019)

[5] https://www.law.go.kr/LSW/lsInfoP.do?efYd=20210205\&lsiSeq=213919\#0000, Sept 22 (2021)

[6] Chungcheongnam-do, 2019 Current Status of Certified Management of Rural Convergence Industry, Chungnam 6th Industrial Center, p.77-91, (2019).

[7] A Study on the 6th Industrial Development Strategy through Statistics and Trends Analysis of Rural Industries, Ministry of Agriculture, Food and Rural Affairs, pp.100-120, (2017)

[8] S. S. Park, Suggestions for the Establishment of a Public Korean 6th Industrialization, International Journal of Tourism Management and Sciences, (2016), Vol.31, No.4, pp.427-434, DOI: 10.21719/KJTR.31.4.21

[9] D. K. Lee, A Study on Development Plan of 6th Agricultural Industrialization Policy: Focus on Agricultural Management Organizations of Chungnam Region, Chungnam National University, Master's thesis, pp.50-77, (2016)

[10] A Study on Future Policy Plans through 6th Industrial Performance Inspection and Evaluation, Ministry of Agriculture, Food and Rural Affairs, pp.15-44, (2017)

[11] D. C. Jung, A Study on the Direction and Task of Fostering the Rural Convergence Industry for Sustainable Rural Areas, Journal of Monthly Public Policy, (2020), Vol.171, pp.57-60.

[12] S. H. Kim, H. S. Jang, D. K. Lee, Y. N. Kwak, S. J. Lee, S. H. Park, K. S. Kang, A Study on the Current Status of the Education Program for the Chung-Nam 6th Industrialization: using AHP, Korean Journal of Agricultural Science, (2019), Vol.46, No.3, pp.519-527, DOI: 10.7744/kjoas.20190035

[13] S. G. Youn, Characteristics of 6th Industrial Type in Gyeongbuk, Dept. of Agriculture and Bio-Convergence, Kyungpook National University, Master's thesis, pp.20-32, (2017)

[14] H. J. Lee, An Analysis of the Determinants of Choice in 6th Industrialization of Agriculture and Farm Income, Dept. of Agricultural Economics and Rural Development, Seoul National University, Master's thesis, pp.28-58, (2017)

[15] Y. J. Seo, J. W. Park, S. Y. Han, D. Y. Hwang, J. H. Yang, 6th Industry Management Body Develop Managerial and Technical Level Metrics-by AHP Analysis, Asia-Pacific Journal of Business Venturing and Entrepreneurship, (2013), Vol.8, No.4, pp.188-202, DOI: 10.16972/apjbve.8.4.201312.188

[16] Y. S. Kim, The Study of Management Efficiency Analysis and Improvement of Agriculture Company Corporation of External Audit, Dept. of Agricultural Economics, Chungnam National University, Master's thesis, pp.62-122, (2015)

[17] Y. J. Kim, S. H. Park, J. S. Park, The Effect of the Sixth Industrial Entrepreneurship by Social Capital on Business Performances, The Journal of Information Systems, (2016), Vol.25, No.3, pp.147-173, DOI: 10.5859/KAIS. 
2016.25.3.147

[18] J. H. Kim, C. H. Jung, Analysis of Management Performance for Development of Rural Convergence Industry : Focusing on Agricultural Management Entities of Government Supports for Rural Industrialization in Chungcheongnam-do, Korean Computers and Accounting Review, (2020), Vol.18, No.1, pp.89-111, DOI: 10.32956/ kaoca.2020.18.1.89

[19] S. J. Choi, A Study on the Effect of Entrepreneurship in Rural Convergence Industry on Management Performance : Focusing on Gangwon-do, Dept. of Green Life Industry Policy, Kangwon National University, Master's thesis, pp.18$27,(2020)$

[20] S. J. Ma, J. I. Kim, G. S. Jung, The 6th Survey on the Status of Professional Human Resources of Industrialization Certification Companies, Korea Rural Economic Institute, pp.5-52, (2015)

[21] J. T. Kim, Exploring the Management Component of Rural Small Business in the 6th Industry at Each Stage of Growth Exploring the Management Component of Rural Small Business in the 6th Industry at Each Stage of Growth, AsiaPacific Journal of Business Venturing and Entrepreneurship, (2017), Vol.12, No.6, pp.123-138, DOI: 10.16972/apjbve.12.6.201712.123

[22] K. C. Kim, A Study on Certification System and Certified Management Bodies for Rural Convergence Industry, Seoul National University, Ph.D dissertation, pp.184-217, (2018)

[23] J. Y. Bian, S. K. Lee, S. B. Kang, The Relationship between Entrepreneurship, Strategic Orientation, and SocioEconomic Values: Focusing on Companies Certified as Sixth, Asia-Pacific Journal of Business Venturing and Entrepreneurship, (2018), Vol.13, No.5, pp.1-16, DOI: 10.16972/apjbve.13.5.201810.1

[24] J. H. Jeon, A Research on Innovation Strategies of Business Supported by Government for the Certified Senary Industry Companies, KyungHee University, Master's thesis, pp.60-122, (2018)

[25] K. H. Song, S. H. Lee, D. K. Jang, A Study on Certified Management Bodies for Rural Convergence Industry Promotion in Jeonnam Province, Korean Journal of Organic Agriculture, (2019), Vol.27, No.2, pp.133-146, DOI: 10.11625/KJOA.2019.27.2.133

[26] Y. K. Park, A Study on the 6th Industrialization Development in Incheon, The Journal of Incheon Studies, (2021), No.35, pp.179-206, DOI: 10.46331/jis.2021.08.35.179

[27] https://www.mafra.go.kr/mafra/401/subview.do, Sept 22 (2021)

[28] A Five-Year Plan for Comprehensive Development of the Rural Convergence Industry in Chungnam, Chungcheongnam-do, ChungNam Institute, pp.7-40, (2018)

[29] Food and Rural Affairs, The 2nd Basic Plan for Rural Convergence Industry, Ministry of Agriculture, Food and Rural Affairs, p.7, (2021)

[30] Y. H. Noh, S. C. Hong, An Empirical Analysis on Stages of Growth in the Korean SME Manufacturing Industry, Journal of the Korean Official Statistics, (2011), Vol.16, No.2, pp.82-109, UCI: G704-001484.2011.16.2.005 